\title{
Diagnostic value of copper parameters to predict growth of suckling calves grazing native range in Argentina ${ }^{1}$
}

\author{
Luis E. Fazzio², Guillermo A. Mattioli², Sebastian J. Picco², Diana E. Rosa², \\ Leonardo Minatel ${ }^{3}$ and Eduardo J. Gimeno ${ }^{2}$
}

\begin{abstract}
Fazzio L.E., Mattioli G.A., Picco S.J., Rosa D.E., Minatel L. \& Gimeno E.J. 2010. Diagnostic value of copper parameters to predict growth of suckling calves grazing native range in Argentina. Pesquisa Veterianária Brasileira 30(10):827-832. Facultad de Ciencias Veterinarias. Universidad Nacional de La Plata, calle 60 y 118 , CC 296, B1900AVW, La Plata, Argentina. E-mail: fazzio@ @cv.unlp.edu.ar

A study was conducted to evaluate the predictive diagnostic value of different copper (Cu) parameters as indicators of average daily gain (ADG) in growing calves. The effects in calves of cow Cu supplementation in the last one-third gestation period were also evaluated. Five supplementation trials, with a total of 300 calves, were carried out. Two groups of 30 calves were randomly assigned to each trial, one group was parenterally supplemented (SG) and the other was not supplemented (NSG). Trials began when calves were three-month-old and ended at weaning time. At each sampling calves were weighed and blood was taken to determine Cu concentrations in plasma, Whole Blood (WB), Red Cells (RC) and Packed Cell Volume (PCV). Liver samples from six animals of each group were taken both at the beginning and at the end of the trial. In two trials the mothers of the SG received Cu supplementation at the last one- third gestation period. Four of the five trials exhibited low ADG in the NSGs. In these groups, plasma Cu concentration decreased rapidly before low ADG was detected, which occurred with values remaining below $25 \mu \mathrm{g} / \mathrm{dl}$. The decrease of RC Cu concentration was considerably slow. WB showed an intermediate position. PCV in the SGs was higher than in the NSGs in all trials. Cow supplementation was insufficient to generate a liver storage able to last after calves reached the 3 months of age. These data could be useful to predict the risk of low ADG in grazing calves.
\end{abstract}

INDEX TERMS: Copper, calves, diagnosis, average daily gain, supplementation.

RESUMO.- [Valor diagnóstico dos parâmetros de cobre para prever o crescimento de bezerros lactantes em pastagem nativas na Argentina.] Foi realizado um estudo para predisser o valor diagnóstico de diferentes parâmetros de cobre $(\mathrm{Cu})$ como indicadores de ganho médio diário (ADG) na criação de bezerros. Também foram avaliados os efeitos da suplementação com Cu nas vacas no último terço da gestação. Cinco ensaios de suplementação, com um total de 300 bezerros, foram realizados. Dois grupos de 30 bezerros foram atribuídos aleatoriamente em cada proba, um grupo foi parenteralmente suple-

\footnotetext{
${ }^{1}$ Received on January 22, 2010.

Accepted for publication on May 28, 2010.

${ }^{2}$ Facultad de Ciencias Veterinarias, Universidad Nacional de La Plata, calle 60 y 118, CC 296, B1900AVW, La Plata, Argentina.

${ }^{3}$ Area de Patología, Facultad de Ciencias Veterinarias, Universidad de Buenos Aires, Av. San Martín 5285, Capital Federal C1417DSY, Argentina. * Corresponding author: fazzio@fcv.unlp.edu.ar
}

mentado (SG) e o outro não foi suplementado (NSG). Os ensaios começaram quando os bezerros tinham três meses de idade e terminou ao tempo do destete. Em cada ensaio os bezerros foram pesados e mostras do sangue foi tomada para determinar as concentrações Cu no plasma, sangue total (WB), eritrócitos (RC) e hematócrito (PCV). Amostras de fígado foram colhidas em seis animais de cada grupo tanto no início quanto no final do ensaio As mães do SG receberam suplementação de Cu no último terço da gestação em dois ensaios. Quatro dos cinco ensaios apresentavam baixa ADG nos NSGs. Nesses grupos, a concentração plasmática de Cu diminuiu rapidamente antes que a baixa do ADG fossei detectada, o que ocorreu com os valores abaixo $25 \mu \mathrm{g} / \mathrm{d}$. A diminuição da concentração de RC Cu foi bastante lenta. WB mostrou uma posição intermédia. PCV nos SGs foi mais elevado do que nos NSGs em todos os ensaios. A suplementação das vacas foi insuficiente para gerar um armazenamento hepático 
capaz de durar até os 3 meses de idade dos bezerros. Estes dados poderiam ser úteis para prever o risco de baixa ADG em bezerros em pastagem.

TERMOS DE INDEXACAO: Cobre, bezerros, diagnóstico, ganância média diária, suplementação.

\section{INTRODUCTION}

Copper deficiency or hypocuprosis is the second most frequent mineral deficiency in grazing cattle in the world, which causes considerable production losses in well characterized areas (Appleton 1992, McDowell 1992, Underwood \& Suttle 1999, Riet-Correa et al. 2007).

In the Salado River Basin (Argentina) more than $50 \%$ of cows are hypocupraemic and this percentage increases to $70 \%$ in calves (Mattioli et al. 1996). This area has 5.5 million cattle, being beef calf breeding the main activity. Production is extensive and it is sustained by natural pastures characterized by low level of $\mathrm{Cu}$ and excessive concentrations of iron (Fe), sulfur (S) and molybdenum (Mo), which reduces the available Cu (Mattioli 1998, Hansen et al. 2008). These conditions are aggravated in association with flooded soils which increase the incidence and severity of illness (Ramirez et al. 1998).

Cu deficiency has been linked to a variety of clinical signs, including achromotrichia, spontaneous fractures, myocardial degeneration, diarrhea and sudden death (Riet Correa et al. 2007, Heidarpour et al. 2008). One of the most important productive consequences of hypocuprosis is low average daily gain (ADG), and it could be unnoticed if the weight of the calves is not regularly controlled (Corah et al. 1996, Mattioli 1998), a common situation in the Salado River Basin.

The diagnosis of hypocuprosis is based on indirect parameters, such as $\mathrm{Cu}$ concentration in different tissues or the activity of $\mathrm{Cu}$-dependent enzymes. Due to its simplicity and low cost, the reference method for herd diagnosis is plasma $\mathrm{Cu}$. Hypocupraemia indicates liver $\mathrm{Cu}$ storage depletion and low Cu supply to tissues, however it decreases rapidly and fails to indicate the beginning of the biochemical alterations at tissue level (Gengelbach et al. 1994, Underwood \& Suttle 1999). Consequently, other indirect parameters that indicated more slowly the Cu variations such us -whole blood (WB) and red cells (RC)-have been proposed (Underwood \& Suttle 1999).

The aim of this study was to evaluate, in the productive context, the predictive diagnostic value of different parameters as indicators of low daily gain risk in calves. The effects in calves of cow Cu supplementation in the last one- third gestation period were also evaluated.

\section{MATERIALS AND METHODS}

Five supplementation trials were carried out on herds in the Salado River Basin. Suckling calves of both sexes remained with their mothers throughout the trial, which began when calves were three-month-old and ended at weaning time (at 6 to 7 months of age). Each trial included two groups of 30 animals, one supplemented group (SG) with $0.3 \mathrm{mg} / \mathrm{kg}$ of $\mathrm{Cu}$ as copper calcium ethylenediamine tetra- acetic acid (Suplenut $囚$ Biogénesis Bagó,
Argentina) injected at every sampling. The other group was not supplemented (NSG) (Table 1). At time of every sampling the weight was controlled and blood was extracted to determine $\mathrm{Cu}$ concentration in plasma, WB, RC and PCV. In six identified

Table 1. Supplementation trials conducted on different farms, years and rainfalls

\begin{tabular}{|c|c|c|c|c|c|}
\hline \multirow[t]{2}{*}{ Trial } & \multicolumn{2}{|c|}{ Animals } & \multirow[t]{2}{*}{ Farm } & \multirow[t]{2}{*}{ Year } & \multirow{2}{*}{$\begin{array}{c}\text { Rainfall (March } \\
\text { to March) }\end{array}$} \\
\hline & $S G^{a}$ & $\mathrm{NSG}^{\mathrm{b}}$ & & & \\
\hline A & 30 & 30 & San Ceferino & 2003-2004 & $914 \mathrm{~mm}$ \\
\hline B & 30 & 30 & $\begin{array}{l}\text { Chacra Exp. } \\
\text { Manantiales }\end{array}$ & 2003-2004 & $914 \mathrm{~mm}$ \\
\hline C & 30 & 30 & El Chaja & 2001-2002 & $1480 \mathrm{~mm}$ \\
\hline $\mathrm{D}$ & 30 & 30 & $\begin{array}{l}\text { Chacra Exp. } \\
\text { Manantiales }\end{array}$ & 2001-2002 & $1480 \mathrm{~mm}$ \\
\hline$E$ & 30 & 30 & $\begin{array}{l}\text { Chacra Exp. } \\
\text { Manantiales }\end{array}$ & $2002-2003$ & $974 \mathrm{mM}$ \\
\hline
\end{tabular}

a Supplemented group, ${ }^{b}$ non-supplemented group.

animals of each group (SG and NSG) liver samples were taken at the beginning and at the end of the trial.

In trials A, B and C the calves were sampled at the $3^{\text {rd }}, 5^{\text {th }}$ and $7^{\text {th }}$ months of age. In trial $D$ the calves were sampled at the $4^{\text {th }}$ and $6^{\text {th }}$ months of age and the mothers of the SG had received $0.15 \mathrm{mg} / \mathrm{kg}$ (Suplenut ${ }^{\circledR}$ Biogénesis Bagó- Argentina) of copper at the last one- third gestation period. In this trial the samples were taken in two opportunities only, because the farm suffered heavy rains and flooding.

In trial $E$ the calves were sampled at the $3^{\text {rd }}, 4^{\text {th }}, 6^{\text {th }}$ and $7^{\text {th }}$ months of age and the mothers of the SG had received $0.15 \mathrm{mg} /$ $\mathrm{kg}$ (Suplenut $囚$ Biogénesis Bagó- Argentina) of copper at the last one- third gestation period.

Blood samples were obtained from calves via jugular venipunture and collected into tubes containing EDTA as anticoagulant. The samples were stored at $4^{\circ} \mathrm{C}$ and processed before 6 hours. Liver samples were obtained by trocar puncture (Erwin et al. 1965). The area between the $11^{\text {th }}$ and $12^{\text {th }}$ ribs on a line between the olecranon and the tuber coxae on the right side was prepared aseptically and anaesthetized by local infiltration of lidocaine hydrochloride $2 \%$. The samples were frozen at $20 C^{\circ}$ until analyzed. An aliquot of WB was deproteinated in equal quantities with $10 \%$ (wt/vol) trichloroacetic acid. Cu was determined by atomic absorption spectrophotometer using the technique described by Pipper \& Higgins (1957) using an GBC 902 (GBC Scientific Equipment Pty Ltd., Dandenong, Victoria, Australia) equipment with acetylene and air flame. The rest of the blood was centrifuged for 15 minutes at $3000 \mathrm{~g}$ and plasma was processed and measured like WB. Cu concentration in RC was determined from WB, plasma and PCV by the following formula [Cu WB - Cu Plasma* (1- PCV/100)) / (PCV/100)] (Ramírez et al. 1993). PCV percentage was obtained by the microhematocrite technique. Liver samples were digested using a mixture of nitric and perchloric acids (1:1) and Cu concentration at the extract was measure as WB.

The ADG was calculated using the following formula [(final weight - initial weight) / № of days]. In trials B, D and E ADG was calculated at first sampling, because weight was recorded at birth time.

The results of each trial were evaluated by the repeated measures into the General Lineal Model procedure of SPSS (version 10.0) statistical package, using treatment (GS and NSG) as between-subjects factor and time (sampling) as within- 
subjects factor in groups. The model included the effects of treatment, time and treatment $x$ time interaction with live weight as covariate. Pair wise comparisons were adjustment for multiple comparisons (Bonferroni) and means difference was significant at 0.05 level.

\section{RESULTS}

Trial A (Table 2). In this trial, differences in ADG between groups were not significant. All the indicators of $\mathrm{Cu}$ status - except for liver Cu concentration - showed significant differences between groups at sampling 2. Plas-

Table 2. Average copper concentration ( \pm standard error) in plasma, whole blood (WB), red cells (RC) and liver, packed cell volume percentage (PCV) and daily weight gain (ADG) in supplemented and non supplemented groups

\begin{tabular}{|c|c|c|c|}
\hline Trial "A" & $\begin{array}{l}1^{\text {st }} \text { sampling } \\
(3 \mathrm{mth} \text { of age })^{\prime}\end{array}$ & $\begin{array}{l}2^{\text {nd }} \text { sampling } \\
(5 \mathrm{mth} \text { of age })\end{array}$ & $\begin{array}{l}3^{\text {rd }} \text { sampling } \\
(7 \mathrm{mth} \text { of age })\end{array}$ \\
\hline & $17( \pm$ & & 51 \\
\hline & $15(=$ & & \\
\hline & $31( \pm$ & & 6 \\
\hline & 0) a & & O B \\
\hline & $59( \pm$ & 79 & a B \\
\hline dl) & 59) a & 67( & b B \\
\hline & $34( \pm 0.73)$ & 37 & ) $\mathrm{B}$ \\
\hline$-F$ & $33( \pm 0.49)$ & b & $b A$ \\
\hline (a) & & 361 & 37)a \\
\hline & & & $5366-2>0$ \\
\hline & & & \\
\hline & $16(+179)$ a & & \\
\hline
\end{tabular}

Different short letters indicate significant differences between groups $(p<0.05)$.

Different capital letters indicate significant differences between sampling $(p<0.05)$.

+ Supplemented group, - non-supplemented group.

Table 3. Average copper concentration ( \pm standard error) in plasma, whole blood (WB), red cells (RC) and liver, packed cell volume percentage (PCV) and daily weight gain (ADG) in supplemented and non supplemented groups

\begin{tabular}{|c|c|c|c|}
\hline Trial "B" & $\begin{array}{c}1^{\text {st }} \text { sampling } \\
\text { (3 mth of age) }\end{array}$ & $\begin{array}{l}2^{\text {nd }} \text { sampling } \\
\text { (5 mth of age) }\end{array}$ & $\begin{array}{l}3^{\text {rd }} \text { sampling } \\
\text { (7 mth of age) }\end{array}$ \\
\hline l) & $44( \pm 5.14)$ a $A$ & 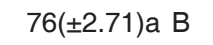 & B \\
\hline & $32=$ & & \\
\hline & 65( & & \\
\hline & 56 & & 41 \\
\hline & a A & 10 & 10 \\
\hline & 86( & 81 & $B$ \\
\hline & 38( & 41 & $B$ \\
\hline \%) & $43( \pm$ & 35 & a B \\
\hline & 40)a $A^{*}$ & 666( & 6)a $\mathrm{C}$ \\
\hline & 3)a $A^{*}$ & $558( \pm 28.24) b$ B & 798 \\
\hline & & & \\
\hline -liver(pp & $15( \pm 6.36) a \mathrm{~A}$ & & $2(0$, \\
\hline
\end{tabular}

Different short letters indicate significant differences between groups $(p<0.05)$.

Different capital letters indicate significant differences between sampling $(\mathrm{p}<0.05)$.

+ Supplemented group, - non-supplemented group. ${ }^{*}$ In this trial the calves were weighed at birth. ma and WB $\mathrm{Cu}$ concentration showed spontaneous recovery in NSG at sampling 2.

Trial B (Table 3). From sampling 2 significant differences in ADG between groups were observed. In sampling 2 of NSG, plasma and WB Cu concentration decreased as well as PCV. In sampling 3 of NSG, plasma Cu and PCV remained stable while $\mathrm{RC} C \mathrm{Cu}$ concentration diminished generating a decrease in WB.

Trial C (Table 4). At first sampling, Cu concentration in

Table 4. Average copper concentration ( \pm standard error) in plasma, whole blood (WB), red cells (RC) and liver, packed cell volume percentage (PCV) and daily weight gain (ADG) in supplemented and non supplemented groups

\begin{tabular}{|c|c|c|c|}
\hline Trial "C" & $\begin{array}{l}1^{\text {st }} \text { sampling } \\
\text { (3 mth of age) }\end{array}$ & $\begin{array}{l}2^{\text {nd }} \text { sampling } \\
\text { ( } 5 \text { mth of age) }\end{array}$ & $\begin{array}{l}3^{\text {rd }} \text { sampling } \\
\text { (7 mth of age) }\end{array}$ \\
\hline 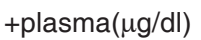 & $18( \pm$ & 38 & 23 \\
\hline & $19( \pm$ & & $\mathrm{A}$ \\
\hline$+\mathrm{WB}$ & NDa & 46( & a $\mathrm{A}$ \\
\hline$-W E$ & $\mathrm{~N}$ & 25( & $\mathrm{b} \mathrm{A}$ \\
\hline$+\mathrm{R}$ & $\mathrm{NL}$ & 59( & a A \\
\hline$-R C$ & $\mathrm{NL}$ & 45( & $\mathrm{b} \mathrm{A}$ \\
\hline$+\operatorname{PCV}(\%)$ & ND & $37( \pm$ & $37( \pm 0.44) a \mathrm{~A}$ \\
\hline$-\operatorname{PCV}(\%)$ & ND & $33( \pm 0.95) b \mathrm{~A}$ & $34( \pm 0.73) b \mathrm{~A}$ \\
\hline$+\mathrm{ADG}(\mathrm{g})$ & & $815( \pm 47.25) a \mathrm{~A}$ & $834( \pm 17.48) a \mathrm{~A}$ \\
\hline$-A D G(g)$ & & $595(61.25) \mathrm{b} \mathrm{A}$ & $617( \pm 43.71) \mathrm{b} \quad \mathrm{A}$ \\
\hline & $23( \pm 5.5$ & & $21( \pm 1.85)$ a $A$ \\
\hline -liver(ppm) & $20( \pm 4.30)$ a A & & $16( \pm 2.02) \mathrm{a} A$ \\
\hline
\end{tabular}

Different short letters indicate significant differences between groups $(p<0.05)$.

Different capital letters indicate significant differences between sampling $(\mathrm{p}<0.05)$

+ Supplemented group, - non-supplemented group, ${ }^{\mathrm{a}}$ not done

Table 5. Average copper concentration ( \pm standard error) in plasma, whole blood (WB), red cells (RC) and liver, packed cell volume percentage (PCV) and daily weight gain (ADG) in supplemented and non supplemented groups

\begin{tabular}{lcc}
\hline Trial "D" & $\begin{array}{c}1^{\text {st }} \text { sampling } \\
(4 \text { mth of age })\end{array}$ & $\begin{array}{c}2^{\text {nd }} \text { sampling } \\
(6 \text { mth of age })\end{array}$ \\
\hline +plasma $(\mu \mathrm{g} / \mathrm{dl})$ & $20( \pm 2.97)$ a A & $61( \pm 4.65)$ a B \\
-plasma $(\mu \mathrm{g} / \mathrm{dl})$ & $12( \pm 1.42)$ b A & $15( \pm 1.33)$ b A \\
+WB $(\mu \mathrm{g} / \mathrm{dl})$ & $39( \pm 2.35)$ a A & $76( \pm 3.46)$ a B \\
-WB $(\mu \mathrm{g} / \mathrm{dl})$ & $29( \pm 1.90)$ b A & $31( \pm 1.68)$ b A \\
+RC $(\mu \mathrm{g} / \mathrm{dl})$ & $73( \pm 2.98)$ a A & $99( \pm 3.14)$ a B \\
-RC $(\mu \mathrm{g} / \mathrm{dl})$ & $58( \pm 3.60)$ b A & $60( \pm 2.93)$ b A \\
+PCV $(\%)$ & $37( \pm 0.78)$ a A & $38( \pm 0.53)$ a A \\
-PCV $(\%)$ & $36( \pm 0.67)$ a A & $36( \pm 0.80)$ a A \\
+ADG $(\mathrm{g})$ & $743( \pm 26.86)$ a A* & $623( \pm 30.84)$ a B \\
-ADG $(\mathrm{g})$ & $697( \pm 30.99)$ a A* & $489( \pm 45.00)$ b B \\
+liver $(p p m)$ & $48( \pm 14.62)$ a A & $94( \pm 25.98)$ a A \\
-liver $(p p m)$ & $23( \pm 4.38)$ a A & $34( \pm 8.57)$ b A
\end{tabular}

Different short letters indicate significant differences between groups $(p<0.05)$.

Different capital letters indicate significant differences between sampling $(p<0.05)$

+ Supplemented group (these calves are born from supplemented cows), - non-supplemented group.* In this trial the calves were weighed at birth. 
Table 6. Average copper concentration ( \pm standard error) in plasma, whole blood (WB), red cells (RC) and liver, packed cell volume percentage (PCV) and daily weight gain (ADG) in supplemented and non supplemented groups

\begin{tabular}{|c|c|c|c|c|}
\hline Trial "E" & $\begin{array}{l}1^{\text {st }} \text { sampling } \\
\text { ( } 3 \mathrm{mth} \text { of age) }\end{array}$ & $\begin{array}{l}2^{\text {nd }} \text { sampling } \\
\text { (4 mth of age) }\end{array}$ & $\begin{array}{l}\text { 3rd sampling } \\
\text { (6 mth of age) }\end{array}$ & $\begin{array}{l}4^{\text {th }} \text { sampling } \\
\text { (7 mth of age) }\end{array}$ \\
\hline I) & $31( \pm$ & & 65 & 62 \\
\hline$/ d$ & 23( & 2 & & \\
\hline$B(\mu \mathrm{g} / \mathrm{dl})$ & $52( \pm$ & 88 & 79 & 79 \\
\hline$(\mu \mathrm{g} / \mathrm{dl})$ & $41( \pm 2.94) \mathrm{b} \mathrm{A}$ & $45( \pm$ & .46)b A & 37)b A \\
\hline$(\mu \mathrm{g} / \mathrm{dl})$ & $92( \pm 5.27) \mathrm{a} \mathrm{A}$ & $130(=$ & $3.02) a$ & 27)a \\
\hline$\mu \mathrm{g} / \mathrm{dl})$ & $79( \pm 4.80) a \mathrm{~A}$ & 0)b B & 45)b & 39)b AE \\
\hline$+\operatorname{PCV}(\%)$ & $35( \pm 0.84)$ a $A$ & i) $a$ & 35( & .77) a \\
\hline - PCV(\%) & $33( \pm 0.84) a A$ & 31 & 35( & a $A$ \\
\hline$+A D$ & $43(+38.94)$ a $A$ & 798 & 8311 & 5.74)a B \\
\hline $\mathrm{AD}$ & $A$ & 7 & 749 & $6.02) \mathrm{b} \mathrm{B}$ \\
\hline & & & & \\
\hline- live & 19 & & & \\
\hline
\end{tabular}

Different short letters indicate significant differences between groups $(p<0.05)$

Different capital letters indicate significant differences between sampling $(p<0.05)$.

+ Supplemented group (these calves are born from supplemented cows), - non-supplemented group. ${ }^{*}$ In this trial the calves were weighed at birth.

WB, RC and PCV could not be measured because the anticoagulant failed. From sampling 2, differences in ADG were observed between SG and NSG. However, plasma, WB, RC and PCV remained constant in the NSG. Nevertheless, in sampling 3 , liver Cu concentration did not show differences between groups.

Trial D (Table 5). Cow supplementation increased plasma, WB and RC Cu concentration in the SG at sampling 1; however PCV and liver Cu concentration did not show differences. In the NSG, parameters remained constant until the sampling 2, where differences in ADG between groups were observed.

Trial E (Table 6). Cow supplementation only caused significant higher WB Cu concentration in sampling 1. Low weight gain in the NSG was observed only at sampling 4. At that time the Cu parameters showed the same values than in sampling 1.

\section{DISCUSSION}

Plasma Cu was too sensible to estimate the risk of reduced $A D G$ risk, since it decreased early and remained low during trials $\mathrm{C}, \mathrm{D}$ and $\mathrm{E}$. Only in trial $\mathrm{B}$ the reduction appeared together with low ADG. Low ADG was observed with plasma Cu concentration of 21 and 22 (trial B), 15 and 16 (trial C), 15 (trial D) and 19 (trial E). For that reasons the predictive value of plasma $\mathrm{Cu}$ seems to be not appropriated. Other authors have observed low ADG with plasma Cu lower than $18 \mu \mathrm{g} / \mathrm{dl}$ (Gengelbach et al. 1994), $20 \mu \mathrm{g} / \mathrm{dl}$ (Humphries et al. 1983), and even over $40 \mu \mathrm{g} / \mathrm{dl}$ (Suttle et al. 1980). These differences between authors may be the result of two factors: (1)a rapid fall of plasma $\mathrm{Cu}$ when there is a deficiency, and (2) the use of herd average values for the affected groups. To rectify the errors caused by the rapid fall of plasma $\mathrm{Cu}$ intervals -rather than punctual valueshave been proposed. Suttle $(1986,1993)$ has proposed plasma Cu concentration lower than $30 \mu \mathrm{g} / \mathrm{dl}$ as the risk range for severe consequences of hypocuprosis. On the other hand, Kincaid (1999) has proposed lower than $20 \mu \mathrm{g} / \mathrm{dl}$ as risk range for clinical manifestations. In the conditions of our trials we use the range of plasma $\mathrm{Cu} \leq 25 \mu \mathrm{g} / \mathrm{dl}$ as an indicator of potential risk of reduced ADG. Plasma $\mathrm{Cu}$ decreases rapidly and should remain low for different periods to observed low ADG. It was observed only $29,39,56$ and 120 days after plasma $C u$ reach critical range in trials $C, B$, $D$ and $E$ respectively. The association between plasma $\mathrm{Cu}$ and ADG was clear in trial A. In that case there was spontaneous recovery of plasma $\mathrm{Cu}$ and ADG was not significantly reduced.

The limitations imposed by a rapid fall of plasma $\mathrm{Cu}$, may be avoided using different parameters which changed more slowly. For example, Suttle (1986) proposed the use of $\mathrm{Cu}$ concentration in RC. In the present study, Cu concentration in RC confirmed this behavior but was not useful for the diagnosis, because it remained stable in three trials ( $C, D$ and $E$ ) decreasing only in trial $B$, but it decreased after low ADG appeared. Besides, we have not found reference values in the published studies.

The Cu concentration in WB was more dependent on plasma $\mathrm{Cu}$ than on $\mathrm{Cu}$ in RC. Cu in WB was the only indicator that decreases progressively throughout a trial (trial B). This is the ideal condition for an indicator which must reflect the progressive deficient status. Koh \& Judson (1986), who measured WB Cu concentration in the same individuals over long periods, suggested that a marginal value is 60 to $100 \mu \mathrm{g} /$ dl. These values are higher than our observations.

In 4 out of the 5 trials (A, B, C and E) Cu supplementation increased PCV percentage in at least in one sampling. The differences were clear between both groups. Regarding trial $\mathrm{D}$, the difference was 38 and $36 \%$ showing a $\mathrm{P}=0.054$. PCV percentage decrease in animals with hypocuprosis which agrees with several previous reports (Underwood 1981, Gengelbach et al. 1994). However this finding is different from such reports because in the present study PCV fall appeared earlier. In previous depletion trials about 20 and 40 
weeks were required to obtain a PCV decrease (Phillippo et al. 1987, Gengelbach et al. 1994), although other authors did not find such decrease after depletion trials lasted 40 weeks (Mills et al. 1976). However, in our study, the groups showed different PCV between weeks 5 and 10. Part of the difference may be explained by the fact that the animals were deficient at sampling 1 . It seems that PCV variations were very sensible and sometimes preceded low ADG. The need for an adequate status of $\mathrm{Cu}$ to maintain the PCV percentage was clear in trial $\mathrm{A}$, where the spontaneous $\mathrm{Cu}$ recovery in NSG was enough to increase plasma $\mathrm{Cu}$ from 15 to $26 \mu \mathrm{g} / \mathrm{dl}$ and even to avoid lower ADG; but it did not improve PCV percentage in comparison with the SG (34 vs. $37 \% \mathrm{P}:<0.01)$. In trial E, PCV differences between groups occurred one month after sampling 1, while lower ADG did not appeared until sampling 4, three months later. Even though it is known that anemia is caused by the lack of $\mathrm{Fe}$ movement from the liver to the hemetopoyetic organs (Mills et al. 1976), it is a late consequence of the deficiency. The early presentation of low PCV in our study could be the result of higher oxidative stress in RC caused by an increase in the production of reactive oxygen species and decrease in antioxidant defenses during hypocuprosis as observed by Picco (2004). This alternative coincides with recent reports on DNA damage in leukocytes, possibly caused by oxidative damage originated when plasma $\mathrm{Cu}$ concentrations are

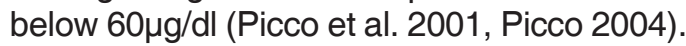

As a preventive measure, Cu supplementation in cows during the last one- third gestation period proved to be useful but insufficient (trials $\mathrm{D}$ and $\mathrm{E}$ ). These results are consistent with those found in previous studies by our group (Fazzio et al. 2006). In the offspring of the supplemented cows hepatic storages were not enough to give normal Cu parameters, that is over $60 \mu \mathrm{g} / \mathrm{dl}$ plasma $\mathrm{Cu}$ and $\geq 100 \mathrm{ppm}$ in liver (Underwood \& Suttle 1999). Nevertheless, there was a clear difference with the offspring of non supplemented cows.

The supplementations in calves sometimes failed to obtain hematic values within normal ranges (trials $A$ and C). It also failed to produce normal hepatic storages $(\geq 100$ $\mathrm{ppm})$. This results show the risk of using parenteral supplementation only at the weaning time as a routinely preventive measure in the Salado River Basin, when calves have an average of 6-7 months, or when clinical signs appear. In a preliminary study Mattioli (2007) improved the $A D G$, at weaning time, in calves that received Cu supplementation in more than one occasion that those who received a single doses at 3 months of age.

The results of our study may improve the diagnosis of low ADG in calves with hypocuprosis. These results permit to evaluate the usefulness of Cu parameters in the diagnosis of ADG in the studied area. As well as in other areas around the world hypocuprosis is highly relevant in cattle production.

These results suggest that lower ADG can be avoided by injectable salts administered in mothers during the last third of gestation and in calves with 3 months of age. This scheme should be strengthened in rainy seasons or flooded soils.
Acknowledgments.- Appreciation is expressed to Drs. Gustavo Melani, Sergio Greco, Ing.Daniel Sarena and Lic. Maria Eugenia Araujo for their assistance during this study. SJP and EJG are Research Members of CONICET (Argentine Research Council).

\section{REFERENCES}

Appleton J.D. 1992. Review of the use of regional geochemical maps for identifying areas where mineral deficiencies or excesses may affect cattle productivity in tropical countries. British Geological Survey Technical Report WC/92/24.

Corah L. 1996. Trace mineral requirements of grazing cattle. Anim. Feed Sci. Technol. 59:61-70.

Erwin E.S., Dyer I.A., Meyer T.O. \& Scott K.W. 1956. Uses of aspiration biopsy technique. J. Anim. Sci. 15:428-434.

Fazzio L.E., Rosa D.E., Picco S.J., Melani G., Minatel L. \& Mattioli G.A. 2006. Efecto de la suplementación parenteral con cobre durante el último tercio de gestación de vacas en zona de hipocuprosis. Revta Vet. 17:84-87.

Gengelbach G.P., Ward J.D. \& Spears J.W. 1994. Effect of dietary copper, iron and molybdenum on growth and copper status of beef cows and calves. J. Anim. Sci. 72:2722-2727.

Hansen S.L., Schlegel P., Legleiter L.R., Lloyd K.E. \& Spears J.W. 2008. Bioavailability of cooper from copper glycinate in steers fed high dietary sulfur and molybdenum. J. Anim. Sci. 86:173-179.

Heidarpour Bami M., Mohri M., Seifi H.A. \& Alavi Tabatabaee A.A. 2008. Effects of parenteral supply of iron and copper on hematology, weight gain, and health in neonatal dairy calves. Vet. Res. Comm. 32:553-561.

Humphries W.R., Phillipo M., Young B.W. \& Bremner Y. 1983. The influence of dietary iron and molybdenum on copper metabolism in calves. Brit. J. Nutr. 49:77-86.

Kincaid R.L. 1999. Assessment of trace mineral status of ruminants: A review. Proc. American Society of Animal Science, Champaign, Illinois, p.1-10.

Koh T.S. \& Judson G.J. 1986. Trace elements in sheep grazing near a lead-zinc smelting complex at Port Pirie, South Australia. Bull. Environ. Contam. Toxicol. 37:87-95.

Mattioli G.A. 1998. Caracterización de la hipocuprosis bovina en el Partido de Magdalena (Provincia de Buenos Aires). Tesis doctoral, Facultad de Ciencias Veterinarias, Universidad Nacional de La Plata. 150p.

Mattioli G.A., Ramírez C.E., Giuliodori M.J., Titarelli C.M., Yano H. \& Matsui T. 1996. Characterization of cattle copper deficiency in the Magdalena District. Livest. Prod. Sci. 47:7-10.

Mattioli G.A., Fazzio L.E., Picco S.J., Rosa D.E., Melani G. \& Palacios A. 2007. Efecto terapéutico de la suplementación estratégica con cobre en terneros de cría. Revta Vet. 18:9-13.

McDowell L.R. 1992. Mineral in Animal and Human Nutrition. Academic Press, New York.

Mills C.F., Dalgarno A.C. \& Wenham G. 1976. Biochemical and pathological changes in tissues of friesian cattle during the experimental induction of copper deficiency. Brit. J. Nutr. 35:309-311.

Phillippo M., Humphries W.R. \& Garthwaite P.H. 1987. The effect of dietary molybdenum and iron on copper status and growth in cattle. J. Agric. Sci. 109:315-320.

Picco S.J. 2004. Consecuencias genotóxicas y clastogénicas en bovinos hipocupremicos. Tesis doctoral, Facultad de Ciencias Veterinarias. Universidad Nacional de La Plata, Argentina. 195p.

Picco S.J., De Luca J.C., Mattioli G.A. \& Dulout F.N. 2001. DNA damage incuced by copper defficiency in cattle assessed by the comet assay. Mutat. Res. 498:1-6.

Piper H.G. \& Higgins G. 1967. Estimation of trace metals in biological material by atomic spectrophotometry. Proc. Assoc. Clin. Biochem. 7:190-195. 
Ramírez C.E., Tittarelli C.M. \& Mattioli G.A. 1993. Un Método Simple para la Medición de $\mathrm{Cu}$, Zn y Mg en Eritrocitos. I Congreso Internacional de la Facultad de Ciencias Veterinarias, Universidad Nacional de La Plata, Argentina. 17p.

Ramírez C.E., Mattioli G.A., Tittarelli C.M., Giuliodori M.J. \& Yano H. 1998. Cattle hypocuprosis in Argentina associated with periodically flooded soils. Livest. Prod. Sci. 55:47-52.

Riet-Correa F. 2007. Deficiência de cobre, p.239-248. In: Riet-Correa F., Schild A.L., Lemos R.A.A. \& Borges J.R.J. (Eds), Doenças de Ruminantes e Eqüinos. Vol.2. 3aㅡ ed. Pallotti, Santa Maria, RS.

Suttle N.F. 1986. Problems in the diagnosis and anticipation of trace element dficiencies in grazing livestock. Vet. Rec. 119:148-152.

Suttle N.F. 1993. The nutritional basis for trace element deficiencies in ruminant livestock, p.19-25. In: Suttle N.F., Gunn R.G., Allen W.M., Linklater K.A. \& Wiener G. (Eds), Trace Elements in Animal Production and Veterinary Practice. BSAP Occ. Publ. no.7, London, UK.

Suttle N.F., Field A.C., Nicolson T.B., Matheson A.D., Prescott J.H.D., Scott N. \& Johnson W.S. 1980. Some problems in assessing the physiological and economic significance of hypocupraemia in beef suckled herds. Vet. Rec. 106:302-304.

Underwood E.J. 1981. Copper, molybdenum and sulphur, p.91-111. In: Ibid. (Ed.), The Mineral Nutrition of Livestock. $2^{\text {nd }}$ ed. Commonwealth Agricultural Bureaux, Farnham Royal, Slough.

Underwood E.J. \& Suttle N.F. 1999. Copper, p.283-342. In: Ibid. (Eds), The Mineral Nutrition of Livestock. $3^{\text {rd }}$ ed. CABI Publishing, New York. 